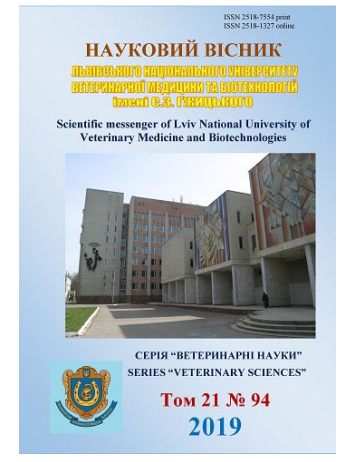

Науковий вісник Дьвівського національного університету ветеринарної медицини та біотехнологій імені С.З. Гжицького.

\author{
Серія: Ветеринарні науки
}

Scientific Messenger of Lviv National University of Veterinary Medicine and Biotechnologies. Series: Veterinary sciences

UDC 619:618.4:6

\title{
Influence of the preparation "Prodevit-tetra" and "Nanovit" on endogenous intoxication of cows during the dry period
}

\author{
Y.S. Stravskyy ${ }^{1}$, V.Y. Stefanyk ${ }^{2}$, V.I. Zavirucha ${ }^{2}$ \\ ${ }^{1}$ Horbachevsky Ternopil National Medical University, Ternopil, Ukraine \\ ${ }^{2}$ Stepan Gzhytskyi National University of Veterinary Medicine and Biotechnologies Lviv, Ukraine
}

Article info

Received 08.04.2019

Received in revised form 08.05 .2019

Accepted 09.05.2019

Horbachevsky Ternopil National Medical University, Maidan Voli 1 Ternopil, 46001, Ukraine.

E-mail:stravskyy@tdmu.edu.ua

Stepan Gzhytskyi National University of Veterinary Medicine and Biotechnologies Lviv, Pekarska Str., 50, Lviv,

79010, Ukraine.

Tel.: +38-050-663-52-12

E-mail: stefanyk@bigmir.net
Stravskyy, Y.S., Stefanyk, V.Y., \& Zavirucha, V.I. (2019). Influence of the preparation "Prodevittetra" and "Nanovit" on endogenous intoxication of cows during the dry period. Scientific Messenger of Lviv National University of Veterinary Medicine and Biotechnologies. Series: Veterinary sciences, 21(94), 74-77. doi: 10.32718/nvlvet9413

It is well known that medium-sized molecules (MSM) affect the tone of smooth muscle structures of organs and the transvascular transport system. MSM also can pass through placental barrier and intoxicate fetus, resulting in multiple organ damage. The goal of the work was to determine the level of endogenous intoxication in cow's organism on the last trimester of pregnancy and under the influence of the "Prodovittetra" and "Nanovit" preparations, as well as calving process and after it. Experiment was conducted in LLC "Agroprodservice invest" of Ternopil oblast on the cows of Ukrainian black-and-white dairy breed. Biochemical studies conducted in the laboratory of veterinary obstetrics and gynecology of the Ternopil Research Station of the Institute of Veterinary Medicine of the NAAS. One control and two experimental groups of animals were used for this experiment. Cows of the first experimental group received $15.0 \mathrm{ml}$ of "Prodevit-tetra" preparation intramuscularly on the 35-25 day before calving. Blood was taken from the observed animals before and after administration of the medicines. The level of endogenous intoxication of the cow's organism were determined by the concentration of MSM in their blood and prooxidant/antioxidant index. Concentration of MSM in the blood of cows after administration of "Prodevit-tetra" reduced by $41.0 \%$ and after administration of "Nanovit" containing metal nanoparticles - by $61.0 \%$ that promoted increase of prooxidant/antioxidant index by 1.7 and 2.3 times $(P \leq 0.001)$ compered to initial indicators and indicated the positive effect of preparations on the cow's organism. Application of the "Nanovit" preparation showed better result, therefore we can recommend it to be used in scheme to reduce intoxication of the cows during the dry period and to prevent postnatal pathology. The results of the experiment suggest that multivitamin complex "Nanovit" could be used for reducing of intoxication in the body of cows during dry period and to prevent postnatal pathology. In the future, we will study effect of the "Nanovit" preparation on the humoral immunity of cows in dry period and after calving and possibility of "Nanovit" usage in the system of prevention of obstetric pathology as well.

Key words: cows, calving, postpartum period, medium-sized molecules, "Prodevit-tetra", "Nanovit".

\section{Вплив препаратів "Продевіт-тетра" i "Нановіт" на ендогенну інтоксикацію організму корів у період сухостою}

\author{
Я.С. Стравський${ }^{1}$ В.Ю. Стефаник ${ }^{2}$ В.І. Завірюха \\ ${ }^{1}$ Тернопільський національний медичний університет імені І.Я. Горбачевського, м. Тернопіль, Украйна \\ ${ }^{2}$ Львівський національний університет ветеринарної медицини та біотехнологій імені С.3. Гюищького, \\ м. Львів, Україна
}


У статті наведені результати визначення рівня ендогенної інтоксикації організму корів у період сухостою. Дослід проведено на коровах украӥнської молочної чорно-рябої породи в ТзОВ “Агропродсервіс-Інвест” Козівського району Тернопільської області. Після запуску корів було сформовано дослідну та контрольну групи (по $n=10)$. Коровам 1-ої дослідної групи за 35-25 діб до отелу,внутрішньом'язово вводили по 15,0 мл препарату “Продевіт-тетра” (1 мл препарату містить вітамін А - 50000 МО, вітамін $D$ - 25000 MO, вітамін E - 20 мг, вітамін F-6 мг). Виробник ТОВ Продукт. Коровам 2-ої дослідної групи за 35-25 діб до отелу, внутрішньом'язево вводили по 5,0 мл мультивітамінний комплекс “Нановіт” (склад: вітаміни A, Д, E; Na та наночастки Си, Zn, Mn, Со). Виробник ТОВ “НВП” “Екологічний капітал”. Встановлено, щуо концентрація молекул середньої маси в крові корів після введення препарату “Продевіт-тетра” знижується на 41,0\% (P $\leq 0,05)$, а після застосування препарату із вмістом наночастинок

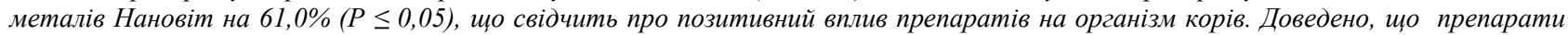
"Продевіт-тетра" $i$ “Нановіт” сприяють, зростання антиоксидантно-проксидантного індексу в $1,7 \quad i \quad 2,3$ рази $(P \leq 0,001)$ відповідно проти показників до введення. Запропоновано препарат “Нановіт” у дозі 5,0 мл на корову за 35-25 діб до отелу використовувати у схемі щодо зниження інтоксикацї організму корів у період сухостою та для профілактики післяродової патологіï.

Ключові слова: корови, роди, післяродовий період, молекули середньої маси, “Продевіт-тетра”, “Нановіт”.

\section{Ветуп}

Надзвичайно важливим моментом акушерської диспансеризації корів $\epsilon$ проведення профілактичного етапу, особливо у сухостійний період. В останні роки у літературі з питань ветеринарної медицини зустрічається термін метафілаксія. Метафілаксія - сукупність заходів, спрямованих на оздоровлення клінічно здорових тварин, але таких, що мають приховані ознаки захворювань. Метою метафілаксії є профілактика та ліквідація захворювань (Kosenko, 1995).

Підвищення рівня продуктів перекисного окиснення ліпідів в організмі корів на останніх місяцях тільності на фоні активації ферментів детоксикації активних форм оксигену свідчить про перебіг ендотоксикозу (Lankin et al., 2001; Revunets, 2006; Gutyj et al., 2017). Дослідженнями (Chander et al., 1988; Fraga et al., 1988) встановлено, що продукти розпаду ліпідів пошкоджують структури клітини, білки, нуклеїнові кислоти, тому вони є ендопатогенами.

Перекисне пошкодження білкових речовин призводить до їхньої деградації і утворення токсичних фрагментів, в тому числі молекул середньої маси (MCM). Накопичення МСМ свідчить про ендотоксикацію, водночас МСМ ускладнюють перебіг патологічного процесу та впливають на життєве забезпечення органів і систем організму загалом (Gerasimov et al., 2004).

Встановлено, що МСМ впливають на тонус гладком'язових структур органів та трансваскулярний транспорт. Також МСМ можуть проникати через плацентарний бар'єр, і таким чином токсини впливають на плід, що призводить до розвитку поліорганих пошкоджень в остатнього (Karjakina \& Belova, 2004).

Мета роботи. Визначити рівень ендогенної інтоксикації організму корів на останньому триместрі тільності та за впливу препаратів “Продевіт-тетра" i “Нановіт” та перебіг у них родів і післяродового періоду.

\section{Матеріал і методи досліджень}

Дослід проведено на коровах української молочної чорно-рябої породи в ТзОВ “Агропродсервіс-Інвест" Козівського району Тернопільської області. Після запуску корів було сформовано дослідну та контрольну групи (по $\mathrm{n}=10)$. Коровам 1-ої дослідної групи за 35-25 діб до отелу, внутрішньом'язово вводили по
15,0 мл препарату “Продевіт-тетра" (1 мл препарату містить вітаміну А - $50000 \mathrm{MO}$, вітаміну D - 25000 MO, вітаміну E - 20 мг, вітаміну F- 6 мг). Виробник ТОВ Продукт. Коровам 2-ої дослідної групи за 35-25 діб до отелу, внутрішньом'язово вводили по 5,0 мл мультивітамінний комплекс "Нановіт" (склад: вітаміни А, Д, Е; Na та наночастки $\mathrm{Cu}, \mathrm{Zn}, \mathrm{Mn}, \mathrm{Co}$ ). Виробник ТОВ “НВП” "Екологічний капітал”.

До і після введення препарату у корів обох груп відбирали кров для проведення біохімічних досліджень. Рівень ендогенної інтоксикації організму корів визначали за концентрацією МСМ в їхній крові і за антиоксидантно-проксидантним індексом. Вміст молекул середньої маси визначали за методикою H.I. Габріелян (Gabrieljan \& Lipatova, 1984).

Контроль за перебігом післяродового періоду проводили відповідно до методики акушерської та гінекологічної диспансеризації корів і телиць (Zvereva et al., 1989).

Статистичну обробку результатів проведено з використанням стандартних комп'ютерних програм 3 визначенням середньої арифметичної (М), статистичної похибки середньої арифметичної $(\mathrm{m})$, вірогідності різниці (Р) між середнім арифметичними двох варіаційних рядів за довірчим коефіцієнтом для різниці середніх (t), коефіцієнта кореляції (r). Різницю між двома величинами вважали вірогідною за *- $\mathrm{P} \leq 0,05$; $* *-\mathrm{P} \leq 0,01 ; * * *-\mathrm{P} \leq 0,001$ (Lakin, 1990).

\section{Результати та їх обговорення}

Рівень ендогенної інтоксикації організму корів визначали за концентрацією МСМ у крові корів і антиоксидантно-проксидантним індексом (табл. 1).

3 даних, наведених у таблиці 1, видно, що концентрація молекул середньої маси в крові корів після введення "Продевіт-тетра" знижується на 41,0\% (P $\leq 0,05)$, а після застосування препарату із вмістом наночастинок металів "Нановіт" на $61,0 \%(\mathrm{P} \leq 0,05)$, що свідчить про позитивний вплив препаратів на організм корів.

Завдяки своїм особливостям вітаміни А, Е і F відіграють важливу роль у забезпеченні структури і функції клітинних мембран, проявляючи при цьому антиоксидантні властивості (Kurtiak \& Yanovych, 2004; Shcherbatyy et al., 2017). 


\section{Таблищя 1}

Вплив препаратів "Продевіт-тетра" і “Нановіт" на вміст молекул середньої маси і антиоксидантнопроксидантний індекс організму корів у період сухостою, $\mathrm{n}=10, \mathrm{M} \pm \mathrm{m}$

\begin{tabular}{|c|c|c|c|c|}
\hline \multirow{3}{*}{ Показники } & \multicolumn{4}{|c|}{ Групи корів } \\
\hline & \multicolumn{3}{|c|}{ "Продевіт-тетра" } & \multirow{2}{*}{$\begin{array}{l}\text { "Нановіт" } \\
\text { після введення }\end{array}$} \\
\hline & до введення & після введення & до введення & \\
\hline Молекули середньої маси г/л & $0,78 \pm 0,02$ & $0,55 \pm 0,01 *$ & $0,79 \pm 0,02$ & $0,49 \pm 0,01 *$ \\
\hline Антиоксидантно-проксидантний індекс & 5,6 & $9,95 * * *$ & 5,1 & $11,9 * * *$ \\
\hline
\end{tabular}

Примітка: *P $\leq 0,05 ; * * * \mathrm{P} \leq 0,001$ порівняно $з$ періодом до введення

Веденні у період сухостою вони забезпечують зниження інтоксикації організму корів та сприяють фізіологічному перебігу родів і післяродовго періоду.

Вільні радикали (оксиданти) - це молекули або їхні частини, що мають неспарений електрон на молекулярній (атомній) орбіті (тобто вільну валентність) (Kurtiak \& Yanovych, 2004; Lavryshyn et al., 2016; Martyshuk et al., 2016; Khariv et al., 2016; Gutyj et al., 2017). Найчастіше вони утворюються в процесі багатоступиневих окисних реакцій, а також у ході реакцій зі зміною валентності елементів. Отже, наночастинки Купруму, Феруму, Цинку, які є у складі "Нановіту" активізують ферментну антиоксидантну систему організму корів шляхом 3'язування неспареного електрону вільних радикалів, а в кінцевому підсумку їх нейтралізації. Беручи до уваги те, що молекули середньої маси є токсинами для організму (Gerasimov et al., 2004; Karjakina \& Belova, 2004), іх вміст можна використовувати як інтегральний показник метаболічних порушень.

Додатковим підтвердженням позитивного впливу препаратів "Продевіт-тетра" і "Нановіт" на організм корів є відповідне зростання антиоксидантнопроксидантного індексу в 1,7 і 2,3 разу $(\mathrm{P} \leq 0,001)$ проти показників до введення.

Отримані нами дані дають підставу вважати, що вітаміни та вітамінні препарати із вмістом наночастинок металів сприяють зниженню ендогенної інтоксикації організму корів в останньому триместрі тільносTi.

Аналізуючи перебіг післяотельного періоду у піддослідних корів, нами встановлено (табл. 2), що після застосування препарату "Нановіт" сервіс-період період у корів був 73,0 доби при індексі осіменіння 1,5, а у корів, яким вводили "Продевіт-тетра", сервіс-період тривав 127 діб при індексі осіменіння 1,7.

Отримані дані свідчать на користь препарату “Нановіт" і дають підставу рекомендувати його у схемі щодо зниження інтоксикації організму корів у період сухостою та для профілактики післяродової патології.

\section{Таблиця 2}

Тривалість сервіс-періоду та індекс осіменіння корів після застосування препаратів "Продевіт-тетра" i "Нановіт" $\mathrm{n}=10, \mathrm{M} \pm \mathrm{m}$

\begin{tabular}{ccc}
\hline Показники & "Продевіт-тетра" & "Нановіт" \\
\hline Сервіс-період & $127,0 \pm 15,0$ & $73,0 \pm 10,0 *$ \\
Індекс осіменіння & 1,7 & 1,5 \\
\hline Примітка: * $-\mathrm{P} \leq 0,05$ стосовно "Продевіт-тетра"
\end{tabular}

\section{Висновки}

1. Препарати “Продевіт-тетра" і “Нановіт”, введені за 35-25 діб до отелу, забезпечують зниженню концентрації молекул середньої маси в крові корів, відповідно, на 41,0\% $(\mathrm{P} \leq 0,05)$ і на $61,0 \%(\mathrm{P} \leq 0,05)$ та сприяють зростанню антиоксидантно-проксидантного індексу в 1,7 і 2,3 разу $(\mathrm{P} \leq 0,001)$ проти показників до введення.

2. Препарат “Нановіт”, введений у дозі 5,0 мл на корову за 35-25 діб до отелу, рекомендується у схемі щодо зниження інтоксикації організму корів у період сухостою та для профілактики післяродової патології.

Заслуговує на увагу вивчення дії препарату "Нановіт" на стан гуморальної ланки імунної системи організму корів у період запуску та після родів і можливість застосування даного препарату в системі профілактики акушерської патології.

\section{References}

Chander, R., Kapoor, N., \& Singh, C. (1988). Lipid peroxidation of the hyperlipemic rat serum lipoproteins in chronic ethanol and acetaldehyde administration. Journal of Biosciences, 13(3), 269-274. doi: 10.1007/BF02712151.

Fraga, C., Leibovitz, G., \& Tappel, A. (1988). Lipid peroxidation measured as thiobarbituric acid reactive substances in tissue slices: characterization and comparison with homogenates and microsomes. Free Rad. Biol. Med., 4(3), 155-161. doi: 10.1016/08915849(88)90023-8.

Gabrieljan, N.I., \& Lipatova, V.I. (1984). Opredelenie soderzhanija srednemolekuljarnyh peptidov krovi pri ostryh formah ishemicheskoj bolezni serdca. Laboratornoe delo, 3, 138-140 (in Russian).

Gerasimov, A.M., Tomsiva L.V., \& Grishakova, M.A. (2004). Molekuly srednej massy u bol'nyh naruzhnym genital'nym endometritom. Klinicheskaja laboratornaja diagnostika, 6, 19-20 (in Russian).

Gutyj, B., Grymak, Y., Drach, M., Bilyk, O., Matsjuk, O., Magrelo, N., Zmiya, M., \& Katsaraba, O. (2017). The impact of endogenous intoxication on biochemical indicators of blood of pregnant cows. Regulatory Mechanisms in Biosystems, 8(3), 438-443. doi: 10.15421/021768.

Gutyj, B., Stybel, V., Darmohray, L., Lavryshyn, Y., Turko, I., Hachak, Y., Shcherbatyy, A., Bushueva, I., Parchenko, V., Kaplaushenko, A., Krushelnytska, O. (2017). Prooxidant-antioxidant balance in the organ- 
ism of bulls (young cattle) after using cadmium load. Ukrainian Journal of Ecology, 7(4), 589-596. doi: $10.15421 / 2017165$.

Gutyj, B.V., Gufriy, D.F., Binkevych, V.Y., Vasiv, R.O., Demus, N.V., Leskiv, K.Y., Binkevych, O.M., \& Pavliv, O.V. (2018). Influence of cadmium loading on glutathione system of antioxidant protection of the bullocks'bodies. Scientific Messenger of Lviv National University of Veterinary Medicine and Biotechnologies, 20(92), 34-40. doi: 10.32718/nvlvet9207.

Karjakina, E.V., \& Belova, S.V. (2004). Molekuly srednej massy kak integral'nyj pokazatel' metabolicheskih narushenij (obzor literatury). Klinicheskaja laboratornaja diagnostika, 3, 4-8 (in Russian).

Khariv, M., Gutyj, B., Butsyak, V., \& Khariv, I. (2016). Hematological indices of rat organisms under conditions of oxidative stress and liposomal preparation action. Biological Bulletin of Bogdan Chmelnitskiy Melitopol State Pedagogical University, 6(1), 276-289. doi: 10.15421/201615.

Kosenko, M.V. (1995). Dyspanseryzatsiia v systemi profilaktyky neplidnosti i kontroliu vidtvornoi funktsii silskohospodarskykh tvaryn. Kyiv, Urozhai (in Ukrainian).

Kurtiak, B.M., \& Yanovych, V.H. (2004). Zhyrorozchynni vitaminy u veterynarnii medytsyni i tvarynnytstvi. Lvov: Triada plius (in Ukrainian).

Lakin, G.F. (1990). Biometrija. M.: Vysshaja shkola (in Russian).

Lankin, V.Z., Tihaze, A.K., \& Belenkov, Ju.M. (2001). Svobodnoradikal'nye processy $\mathrm{v}$ norme i pri patologicheskih sostojanijah: posobie dlja vrachej. Moskva: Nauka (in Russian).

Lavryshyn, Y.Y., Varkholyak, I.S., Martyschuk, T.V., Guta, Z.A., Ivankiv, L.B., Paladischuk, O.R., Murska,
S.D., Gutyj, B.V., \& Gufriy, D.F. (2016). The biological significance of the antioxidant defense system of animals body. Scientific Messenger of Lviv National University of Veterinary Medicine and Biotechnologies named after S.Z. Gzhytskyj, 18(66), 100-111. doi: $10.15421 /$ nvlvet6622.

Martyshuk, T.V., Gutyj, B.V., \& Vishchur, O.I. (2016). Level of lipid peroxidation products in the blood of rats under the influence of oxidative stress and under the action of liposomal preparation of " $\mathrm{Bu}$ taselmevit', Biological Bulletin of Bogdan Chmelnitskiy Melitopol State Pedagogical University, 6 (2), 22-27. doi: 10.15421/201631.

Melamed, F., Lache, O., Enay, B.L. et al. (2001). Structure - function analysis of the antioxidant properties of haptoglobin. Blood, 98(13), 3693-3698. https:/www.ncbi.nlm.nih.gov/pubmed/11739174.

Revunets, A.S. (2006). Vplyv adsorbentiv na perebih tilnosti, otelennia i pisliaotelnoho periodu rodiv $u$ koriv v zoni radiatsiinoho zabrudnennia: avtoref. dys. na zdobuttia nauk. stupenia kand. vet. nauk: spets. 16.00.07 "Veterynarne akusherstvo". Kharkiv (in Ukrainian).

Shcherbatyy, A.G., Slivinska, L.G., Gutyj, B.V., Golovakha, V.I., Piddubnyak, A.V., \& Fedorovuch, V.L. (2017). The influence of a mineral-vitamin premix on the metabolism of pregnant horses with microelemetosis. Regulatory Mechanisms in Biosystems, 8(2), 393398. doi: 10.15421/021746.

Zvereva, G.V., Homin, S.P., \& Oleskiv, V.N. (1989). Metodika akusherskoj i ginekologicheskoj dispanserizacii korov i telok. L'vov: L'vovskij zooveterinarnyj institut (in Russian). 